\title{
Heterotopic brain tissue in the lung causing acute respiratory distress in an infant
}

\author{
CLARE FULLER, ALLEN R GIBBS \\ From the Department of Histopathology, University Hospital of Wales, Cardiff, and Llandough Hospital, \\ Penarth
}

\begin{abstract}
A three month male infant with a 24 hour history of cyanotic attacks was found to have heterotopic brain tissue at thoracotomy. He has remained well over 20 years of follow up. The pathogenesis of the condition is discussed.
\end{abstract}

We report a case of heterotopic brain tissue in the lung of a three month old male infant presenting with cyanotic attacks. Only one previous case of brain heterotopia in the lung causing neonatal respiratory distress has been described.'

\section{Case report}

A 3 month old male infant presented with a 24 hour history of repeated cyanotic attacks. The child was born after an uneventful pregnancy and spontaneous vaginal delivery. At birth he was found to have a cleft lip and cleft hard and soft palate, but no other congenital abnormalities. The child was fed by spoon and was gaining weight normally. No corrective surgery had been undertaken. A chest radiograph on admission showed a large tension cyst in the right chest, displacement of the heart to the left, and anterior herniation of the mediastinum. The infant was taken to the operating theatre and a needle was inserted into the right chest cavity with the release of some air, but little clinical improvement occurred. A thoracotomy was hurriedly performed. A large thin walled cyst in the upper lobe and two large cysts in the lower lobe of the right lung were resected. The child made an uneventful recovery and subsequently had surgery to correct his cleft lip and palate. He was followed as an outpatient for 20 years and showed normal mental and physical development.

\section{PATHOLOGICAL FINDINGS}

Three collapsed cysts were received, measuring 7, 2.5, and $2 \mathrm{~cm}$ in diameter. Microscopic examination showed that the cyst walls were composed of mature neural tissue with neurones, glial cells, and glial fibres (the glial fibres stained with phosphotungstic acid haemotoxylin). Within the neural tissue were irregular ductal structures lined by ciliated columnar epithelium similar in appearance to the bronchiolar epithelium in the surrounding rim of haemorrhagic

Address for reprint requests: Dr C Fuller, Department of Histopathology, University Hospital of Wales, Cardiff CF4 4XN.

Accepted 2 October 1989

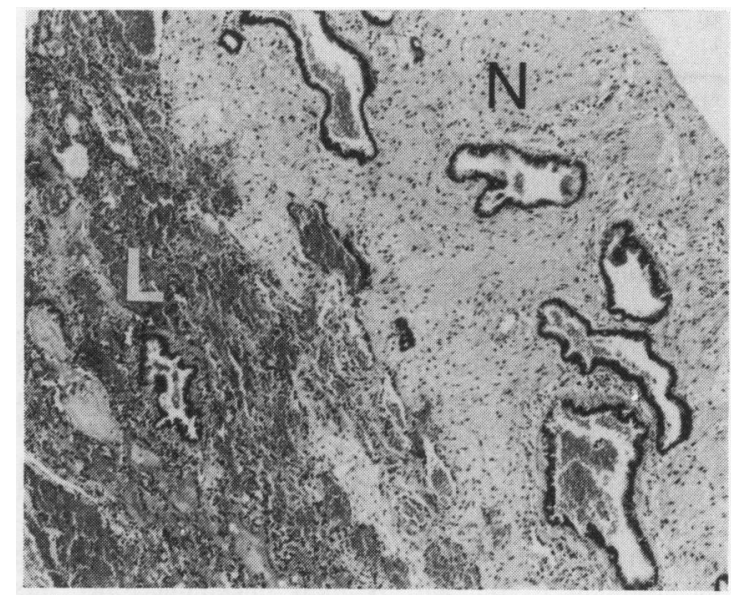

(A)

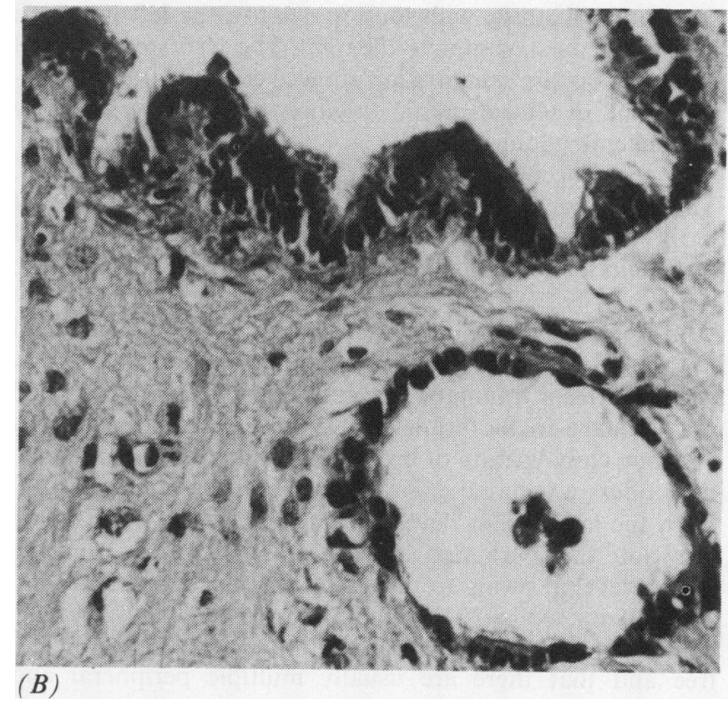

A: Neuroglial tissue $(N)$ containing tubules adjacent to collapsed, haemorrhagic lung ( $L) ;$ a cyst cavity is seen top right.

B: Tubules lined by ciliated epithelium lying in a background of neuroglial tissue. 
Published cases of brain heterotopia

\begin{tabular}{|c|c|c|c|c|c|}
\hline Case No & Age at death (sex) & Congenital abnormality & Symptoms & \multicolumn{2}{|c|}{ Reference } \\
\hline 1 & Newborn & Microcephaly, encephalocele & None & 5 & $(1908)$ \\
\hline 2 & 4 y (M) & Frontal meningocele & None & 6 & (1929) \\
\hline 3 & 51 y (M) & None & None & 7 & (1938) \\
\hline 4 & $2 \mathrm{~d}(\mathrm{~F})$ & Anencephaly & None & 3 & (1941) \\
\hline 5 & Stillborn (F) & Anencephaly & - & 8 & (1942) \\
\hline 6 & $4 \mathrm{~d}(\mathrm{M})$ & Anencephaly & None & 8 & (1942) \\
\hline 7 & $5 \mathrm{~h}(\mathrm{~F})$ & Anencephaly, cleft palate, talipes equinovarus & None & 9 & (1979) \\
\hline 8 & Adult (F) still alive* & $\begin{array}{l}\text { Mental retardation, micrognathia, tongue tie, } \\
\text { incurving 5th digit, cleft lip and palate }\end{array}$ & $\begin{array}{l}\text { Respiratory distress at } \\
\text { birth and at } 3 \text { months }\end{array}$ & 1 & (1980) \\
\hline 9 & $12 \min (F)$ & $\begin{array}{l}\text { Anencephaly, severe abnormality of left face, } \\
\text { anterior spina bifida }\end{array}$ & None & 10 & $(1981)$ \\
\hline $\begin{array}{l}10 \\
11\end{array}$ & $\begin{array}{l}30 \min (M) \\
\text { Stillborn }(M)\end{array}$ & $\begin{array}{l}\text { Anencephaly, gastroschisis } \\
\text { Anencephaly }\end{array}$ & None & $\begin{array}{l}4 \\
2\end{array}$ & $\begin{array}{l}(1982) \\
(1987)\end{array}$ \\
\hline
\end{tabular}

${ }^{*}$ Described in the discussion.

collapsed lung tissue. The cyst cavity was without an epithelial cell lining (figure).

\section{Discussion}

Distal heterotopia of brain tissue is rare. Eleven cases have been reported ${ }^{2}$ and in all of them the brain tissue was located in the lung (table). In nine of the cases heterotopic brain tissue was an incidental finding at necropsy in neonates and infants with anencephaly. Case 8 shows similarities to our own.' This infant had respiratory distress from birth. A chest radiograph showed cystic change affecting the whole of the right lung and the mid zone of the left lung with shifting of the mediastinum to the left. A right pneumonectomy was performed. The lung contained multiple deposits of neural tissue. The child presented again three months later in severe respiratory distress, with tension cysts in the left lung and shift of the mediastinum to the right. The cysts were resected and microscopic examination showed neuroglial tissue surrounding distended cystic cavities lined by respiratory ciliated epithelium.

The pathogenesis of distal brain heterotopia is uncertain. The theories most favoured are: (1) systemic embolisation of brain tissue after intrauterine trauma; (2) aspiration of fragments of brain tissue from the amniotic fluid into the lungs. ${ }^{4}$

In support of the first theory is the well documented necropsy finding of brain tissue emboli within the pulmonary arteries after a traumatic forceps delivery. ${ }^{3}$ It is postulated that damage to the brain during the first trimester causes systemic embolisation of brain tissue, but that only the fetal lung offers a suitable environment for subsequent growth. With the subsequent development of the lung the bronchi grow into the neural tissue but alveoli, muscle, and cartilage fail to develop owing to the effect of the abnormal stroma. This theory explains the finding that the duct structures within the brain tissue are in continuity with the bronchial tree and that there are usually multiple peripheral and subpleural areas of neural tissue. Against the second theory is the fact that intrauterine respiratory movements are shallow and insufficient to carry brain tissue out to the lung periphery. Only during birth hypoxia are respiratory movements sufficient to carry amniotic fluid into the peripheral alveoli.

In summary, we present a case of heterotopic brain tissue within the lung causing tension cysts and respiratory distress in a 3 month old infant with cleft lip and palate. This case is unusual in that the child was without anencephaly and of normal intelligence.

\section{References}

1 Gonzalez-Crussi F, Boggs JD, Raffensperger JG. Brai heterotopia in the lungs. A rare case of respiratory distress in the newborn. Am J Clin Pathol 1980;73:281-3.

2 Rakestraw MR, Masood S, Ballinger WE. Brain heterotopia and anencephaly. Arch Pathol Lab Med 1987;111:858-60.

3 Gruenwald PMD. Emboli of brain tissue in fetal lungs. Am J Pathol 1941;17:879-84.

4 Chen W, Kelly MM, Shaw C, Mottet NK. Pathogenetic mechanisms of heterotopic neural tissue associated with anencephaly. Hum Pathol 1982;13:179-82.

5 Askanazy M. Contribution to the relationship between malformation and tumour based on an observation of a unique encephalocele with gliomas in the lung. Arch Path Anat Inst Tubingen 1908;6:433.

6 Huckel R. On ectopic glial tissue in the lung of a newborn with frontal encephalocele. Verhandl Deutsch Path Gesellsch 1929; 24:272.

7 King WI. Tumour (embryoma) of lung containing brain tissue. Med Bul VA 1938;15:181.

8 Potter EL, Young RL. Hetertopic brain tissue in the lung of two anencephalic monsters. Arch Pathol 1942;34:1009.

9 Kanbour AI, Barmada MA, Klionsky B, et al. Anencephaly and heterotopic central nervous tissue in lungs. Arch Pathol Lab Med 1979;103:116.

10 Campo E, Bombi JA. Central nervous system heterotopia in the lung of a fetus with cranial malformation. Virchovs Arch $A$ 1981;391:117-22. 